\title{
SUCCESSFUL MANAGEMENT OF STUTTERING PRIAPISM USING HOME SELF-INJECTIONS OF THE ALPHA-AGONIST METARAMINOL
}

\author{
MICHAEL McDONALD, RICHARD A. SANTUCCI \\ Division of Urology, Wayne State University, Detroit, Michigan, USA
}

\begin{abstract}
Low-flow priapism can result in impotence if treatment is delayed, yet patients with recurrent priapism often suffer delay before therapy. We describe management of recurrent priapism using selfadministered injections of intracavernosal metaraminol (Aramine ${ }^{\mathrm{TM}}$, Merck), a long-acting vasoconstricting amine that is considered safer than epinephrine. The patient injects as often as once daily using 5-10 mg of drug. Our patient reports rapid detumescence and has not required emergency room visits since starting injections. He denies complications. Treatment of priapism using metaraminol has been suggested in the hospital setting; however, this is the first report of successful home selfadministration of the drug.
\end{abstract}

Key words: priapism, alpha-agonist, metaraminol, Aramine

Int Braz J Urol. 2004; 30: 121-122

\section{INTRODUCTION}

Low-flow priapism can result in impotence if treatment is delayed. Some affected individuals admit to significant time delay before they seek medical attention, and report still further delays due to delays in the emergency room. We describe successful management of stuttering priapism using self-intracorporeal injection of metaraminol bitartrate (Aramine $^{\mathrm{TM}}$, Merck) in one patient with low-flow priapism secondary to sickle cell trait. Metaraminol is a long-acting vasoconstricting sympathomimetic amine with strong $\alpha$ activity and weak $\beta_{1}$ activity. It is used primary to increase blood pressure in cases of shock, or in cases of hypotension during surgical anesthesia. It is considered safer than epinephrine, another well-known $\alpha$-agonist.

\section{CASE REPORT}

A 38-year-old African-American male with sickle cell trait and recurrent priapism has been performing self-injections at home with intracorporal metaraminol since 1992. The patient's past medical history is otherwise unremarkable. He injects as often as once every other day for up to 3 weeks, followed by months without the need for injection, using 5-10 $\mathrm{mg}$ of metaraminol $(10 \mathrm{mg} / \mathrm{cc}$ concentration $-10 \mathrm{mg}$ is the maximum subcutaneous dosage recommended in the Physician's Desk Reference.) The patient starts with $5 \mathrm{mg}$ and reinjects another $5 \mathrm{mg}$ if detumescence does not occur, using a $1 \mathrm{cc}$ insulin syringe with 28 gauge needle and a lateral corporal injection site. The patient reports complete detumescence within 3-10 minutes after injection. He has not reported emergency room visits since starting self-injections, pain with injections, or any systemic side effects associated with sympathomimetics such as headache, shortness of breath, flushing or chest pain. He has normal erectile dysfunction and an unremarkable physical exam, including no signs of intracorporeal fibrosis at the injection site.

\section{DISCUSSION}

Successful treatment of priapism using intracavernosal injections of metaraminol was first 
suggested by Brindley in 1984 (1), yet selfadministered home treatment has not to our knowledge been yet reported. Self-injection with epinephrine has been previously described (2), but we and others believe that the strong $\beta$-agonists' effects of this drug make it less attractive than metaraminol because $\beta$-agonism is associated with cardiac arrhythmia.

Alpha-agonists like metaraminol are contraindicated in patients with uncontrolled hypertension, coronary insufficiency, a history of arrhythmia, and in those taking monoamine oxidase inhibitors. It should be used with caution in those with hyperthyroidism. Overdosage is associated with hypertension, which can results in flash pulmonary edema, coronary ischemia, cardiac arrhythmia, and death (3). The drug is not United States Federal Drug Administration (US-FDA) approved for the treatment of priapism, although neither are other sympathomimetics in common use. They are given under the legal and ethical standards that protect non-
FDA approved treatments that conform to "standard of care".

Home therapy with metaraminol or other sympathomimetics should not be undertaken until several doses have been used in a monitored hospital setting. Only once patients tolerate the procedure in the hospital without significant blood pressure changes can it be advised for home use. This report suggests another tool in the armamentarium against the difficult problem of recurrent priapism.

\section{REFERENCES}

1. Brindley GS: New treatment for priapism. Lancet. 1984; 2: 220-1.

2. van Driel MF, Joosten EA, Mensink HJ: Intracorporeal self-injection with epinephrine as treatment for idiopathic recurrent priapism. Eur Urol. 1990; 17: 956.

3. Physician's Desk Reference, 58th ed. Montvale, NJ, Medical Economics, Thomson Healthcare, p. 3000, 2004.
Received: December 14, 2003

Accepted: January 20, 2004

\author{
Correspondence address: \\ Dr. Richard Santucci \\ Dept Urology, Wayne State University \\ 4160 John R., Suite 1017 \\ Detroit, Michigan, 48201, USA \\ Fax: + 1 313-745-0464 \\ E-mail: rsantucc@med.wayne.edu
}

